$<$ JWL $25(6)>$

\title{
<Title> The pluralism of river rights in Aotearoa, New Zealand and Colombia
}

<authors>Elizabeth Macpherson

Felipe Clavijo Ospina

In this article we interrogate the recognition of rivers as legal persons in Aotearoa New Zealand (Whanganui River) and Colombia (Río Atrato). Although the legal, political, historical and cultural context for recognition is different in each country, an analysis of the cases presents some interesting conceptual correlations, which help us to understand this emerging (and sometimes controversial) transnational idea that a river can be a person. In both cases recognising that the river is a person is an attempt to accommodate diverse legal and cultural interests in the river, in order to establish a new collaborative relationship between the state and river communities. Whether either model results in improved river outcomes, or increased indigenous or community jurisdiction to govern, turns not on the fiction that the river is a person but on the surrounding institutional framework, which has been carefully designed to engender enforceability. Thus, we argue, traditional dichotomies that draw lines between humancentred and earth-centred laws or as the object versus the subject of property or rights fail to capture what legal personality entails.

Ahora es el momento de comenzar a tomar las primeras medidas para proteger de forma eficaz al planeta y a sus recursos antes de que sea demasiado tarde o el daño sea irreversible, no solo para las futuras generaciones sino para la especie humana.

\footnotetext{
${ }^{*}$ Dr Elizabeth Macpherson is a Law Lecturer at the University of Canterbury. Felipe Clavijo Ospina is constitutionalist from the National University of Colombia, a former law clerk at the Constitutional Court of Colombia and professor at the Universidad Externado de Colombia and currently works at the Procuraduría General de la Nación of Colombia. The authors would like to thank Dr Erin O'Donnell (University of Melbourne) for her intellectual engagement with ideas in this article and the Centre for Resources, Energy and Environmental Law at the University of Melbourne and Departamento de Derecho Constitutional at the Universidad Externado de Colombia for allowing them to present the ideas in this article for feedback. All mistakes are the authors' alone.

${ }^{1}$ Centro de Estudios para la Justicia Social 'Tierra Digna' and Others $v$ President of the Republic and Others No T-622 of 2016, Corte Constitucional [Constitutional Court], Sala Sexta de Revision [Sixth Chamber] (Colombia) (10 November 2016) 137 (Tierra Digna).
} 
Now is the moment to begin to take the first steps effectively to protect the planet and its resources before it is too late or the damage is irreversible, not just for future generations but for the human species.

\section{$<A>1$ Introduction}

In the past year there have been two discrete cases, in very different parts of the world, where rivers have been declared to be 'legal persons'. ${ }^{3}$ Much academic and political attention has been given to the case of the Whanganui River in Aotearoa, New Zealand, declared by legislation to be a legal person in March 2017. ${ }^{4}$ Less well known is the case of the Río Atrato in Colombia, recognised as a legal person by the domestic Constitutional Court in November 2016, in a decision not released publicly until May $2017 .{ }^{5}$ Both cases have been lauded by environmentalists as the personification of the inherent rights of nature. ${ }^{6}$ But what does it mean to recognise that a river is a legal person in such vastly different places? In the particular contexts in which the Colombian and New Zealand cases have taken place, what is the nature and content of the rights that are recognised?

In this article the key features of the legal person model adopted in each of the New Zealand and Colombian cases are interrogated and the challenges posed by those

\footnotetext{
${ }^{3}$ Elizabeth Macpherson, Erin O'Donnell and Felipe Clavijo Ospina, 'Meet the River People: Who Speaks for the Rivers?' Stuff, 2 April 2018 http://www.stuff.co.nz/environment/102741097/meet-theriver-people-who-speaks-for-the-rivers; Elizabeth Macpherson and Erin O’Donnell '¿Necesitan Derechos Los Ríos? Comparando Estructuras Legales Para Regulación de Ríos En Nueva Zelanda, Australia y Chile [Do Rivers Need Rights? Comparing Legal Structures for River Regulation in New Zealand, Australia and Chile]' Paper presented to the Jornadas de Derecho de Aguas, Pontificia Universidad Catolica de Chile, 2017; Erin O'Donnell 'At the intersection of the sacred and the legal: rights for nature in Uttarakhand, India' (2018) 30(1) Journal of Environmental Law 1; Katherine Sanders "Beyond human ownership"? Property, power, and legal personality for nature in Aotearoa New Zealand' (2017) Journal of Environmental Law 1.

${ }^{4}$ Indicative of its significance, an opinion piece on the Te Awa Tupua Act by O'Donnell and TalbotJones on The Conversation attained more than 120,000 views in the space of three months. See Erin O'Donnell and Julia Talbot-Jones 'Three rivers are now legally people - but that's just the start of looking after them' (The Conversation 2017) http://theconversation.com/three-rivers-are-now-legallypeople-but-thats-just-the-start-of-looking-after-them-74983.

${ }^{5}$ Tierra Digna (n 2).

${ }^{6}$ See eg Global Alliance for the Rights of Nature Rights of Nature https://therightsofnature.org/?p=37208.
} 
features in the local context explored. ${ }^{7}$ It is argued that, although there are obvious contextual differences, there are interesting commonalities in the recognition of rivers as legal persons across the New Zealand and Colombian models, which might herald the emergence of a (loose) transnational concept of legal rights for rivers. Legal person models are typically presented as indicative of an 'ecocentric' tendency in the regulation of natural resources, in which nature is the subject rather than the object of rights. ${ }^{8}$ However, the New Zealand and Colombian cases are 'culturally located', in the sense that river rights are a consequence of the recognition of the (human) rights of indigenous and tribal peoples as river communities. Further, while the implementation of the Colombian and New Zealand models has just begun, in both cases the efficacy of rivers as persons will depend on strong institutions, governed by humans, to enforce river rights.

\section{$<\mathrm{A}>2$ The pluralism of river rights}

\section{$<B>2.1 \quad$ Legal personality as ecocentrism}

Rivers have long been valued for their utility, both economic and social, to humans. Legal frameworks that regulate the management and use of water have done so with these values in mind - water resources must be efficiently allocated and managed so that humans might continue to benefit from them. This approach, known in the field of natural resources regulation as an 'anthropocentric' one, has formed the basis for water

\footnotetext{
${ }^{7}$ In this article a contextual approach to comparative legal research is taken, by analysing laws and policies in their historical, economic, cultural or political contexts. See A Esin Orucu 'Methodology of comparative law' in J M Smits Elgar (ed) Encyclopedia of Comparative Law (Edward Elgar Publishing 2006) 442, 445; Mark van Hoeke 'Deep level comparative law' in Mark van Hoeke (ed) Epistemology and Methodology of Comparative Law (Hart Publishing 2004) 165, 165; Maurice Adams 'Doing what doesn't come naturally. On the distinctiveness of comparative law' in Mark van Hoecke (ed) Methodologies of Legal Research: What Kind of Method for What Kind of Discipline? (Hart Publishing 2011) 238; Douglas W Vick 'Interdisciplinarity and the discipline of law' (2004) 31(2) Journal of Law and Society 163, 184.

${ }^{8}$ See eg Meg Good 'The river as a legal person: evaluating nature rights-based approaches to environmental protection in Australia' (2013) 1 National Environmental Law Review 34; Michelle Maloney 'Building an alternative jurisprudence for the earth: the International Rights of Nature Tribunal' (2016) 1 Vermont Law Review 129; Vito de Lucia 'Towards an ecological philosophy of law: a comparative discussion' (2013) 4(2) Journal of Human Rights and the Environment 167.
} 
laws throughout the world, both at international level and within domestic laws and policies. ${ }^{9}$

Pursuant to an alternative 'ecocentric' theory, nature is conceived of as the object of rights, and not merely a subject for human exploitation. ${ }^{10}$ Conversely, humans, who have historically used and abused natural resources, owe obligations to nature, to protect nature's rights and interests. Ecocentrism evolved out of deep or green ecology movements of the 1960s, which opposed anthropocentrism and its propertised, utilitarian view of nature. ${ }^{11}$ In law, ecocentrism inspired the development of "earth jurisprudence', which emphasises that 'humanity and the non-human world belong to the same moral order' as members of earth's community, ${ }^{12}$ demanding fundamental change in law and regulation. ${ }^{13}$ Proponents of earth jurisprudence often point to a dichotomy between human rights to property in natural resources versus the inherent, inalienable rights of nature. ${ }^{14}$ Somewhat ironically, earth jurisprudence has co-opted the very human concept of 'rights' to secure nature's protection. ${ }^{15}$

The first example typically put forward of such ecocentric laws comes from Ecuador, where the rights of 'Pachamama' (Mother Earth) were recognised and protected in the 2008 Constitution. ${ }^{16}$ In 2009 Bolivia also recognised the rights of Mother Nature in its

\footnotetext{
${ }^{9}$ Elisa Morgera and Kati Kulovesi Research Handbook on International Law and Natural Resources (Edward Elgar Publishing 2016) 5; B Donnelly and P Bishop 'Natural law and ecocentrism' (2006) 19(1) Journal of Environmental Law 89, 90; Catherine J Irons Magallanes 'Maori cultural rights in Aotearoa New Zealand: protecting the cosmology that protects the environment' (2015) 21(2) Widener Law Review 273, 275.

${ }^{10}$ Good (n 8) 34. Good suggests that it could be argued that the Earth has a 'right to life', and it is from this right that the rights of nature are sourced.

${ }^{11}$ Christopher D Stone Should Trees Have Standing? : Law, Morality, and the Environment (Oxford University Press 2010).

${ }^{12}$ See de Lucia (n 8) 188; Thomas Berry The Great Work: Our Way into the Future (Bell Tower 1999) 4.

${ }^{13}$ Michelle Maloney and Peter Burdon Wild Law: In Practice (Taylor and Francis 2014); Maloney (n 8) 132; Sophia Imran, Khorshed Alam and Narelle Beaumont 'Reinterpreting the definition of sustainable development for a more ecocentric reorientation: reinterpreting the definition of sustainable development' (2014) 22(2) Sustainable Development 134; Arturo Escobar Encountering Development: The Making and Unmaking of the Third World (Princeton University Press 1995).

${ }^{14}$ Abigail Hutchison 'Whanganui River as a legal person' (2014) 3 Alternative Law Journal (Gaunt) 179, 179; Mari Margil 'The standing of trees: why nature needs legal rights' (2017) 34(2) World Policy Journal 8.

${ }^{15}$ According to liberal political theory, 'rights' protect 'fundamental human interests'. See Duncan Ivison 'The logic of Aboriginal rights' (2003) 3(3) Ethnicities 321, 322-24.

${ }^{16}$ Constitución de la República del Ecuador 2008 (Ecuador).
} 
Constitution and Law of the Rights of Mother Earth. ${ }^{17}$ A number of recent legal and political developments concerning the rights of nature have involved declarations that rivers are 'legal persons': that is, that rivers are the subject of legal rights and have the necessary standing to sue and be sued, enter into contracts, and hold property in their own name. ${ }^{18}$ In most Western legal systems, at least those evolving out of the Roman law tradition, 'legal persons' are restricted to natural persons (individuals), corporations, and ships. ${ }^{19}$ Giving rivers legal personality is intended to provide them with the standing humans and corporations have to protect their interests against others, where necessary in the courts. ${ }^{20}$

The first legislative recognition of a river as a legal person occurred in New Zealand in March 2017, when the Whanganui River (Te Awa Tupua) was declared to be a legal person under a political settlement between the New Zealand government and Māori of the Whanganui Iwi (tribe). ${ }^{21}$ The Te Awa Tupua (Whanganui River Claims Settlement) Act 2017 (Te Awa Tupua Act) declares that the Whanganui River is a legal person, with 'all the rights, powers, duties, and liabilities of a legal person' 22 and devises a complicated collaborative governance regime, presided over by a 'guardian' called 'Te Pou Tupua', to act in the interests of the river and enforce its rights. ${ }^{23}$

The legal person approach appears to be gaining some transnational traction. A similar approach was adopted by a regional Court for rivers in India in April 2017, ${ }^{24}$ although the decisions are currently subject to appeal. ${ }^{25}$ In May of the same year the Constitutional Court of Colombia released its decision recognising the Río Atrato as a

\footnotetext{
${ }^{17}$ Constitución Política del Estado 2009 (Bolivia); Ley de Derechos de la Madre Tierra (Ley 071) 2010 (Bolivia).

${ }^{18} \mathrm{~S}$ M Solaiman 'Legal personality of robots, corporations, idols and chimpanzees: a quest for legitimacy' (2017) 2 Artificial Intelligence and Law 155, 157.

${ }^{19}$ M Davies and N Naffine Are Persons Property? Legal Debates about Property and Personality (Ashgate Publishing 2001).

${ }^{20}$ Erin O'Donnell Constructing the Aquatic Environment as a Legal Subject: Legal Rights, Market Participation, and the Power of Narrative (PhD Thesis, University of Melbourne 2017).

${ }^{21}$ Te Awa Tupua (Whanganui River Claims Settlement) Act 2017 (NZ) (Te Awa Tupua Act). In this article, for simplicity, reference is made to the 'Whanganui Iwi', although it is acknowledged that a number of other iwi (tribes) and hapu (subtribes) have interests in the Whanganui River.

22 ibid s 14.

23 ibid s 18.

${ }^{24}$ Mohd Salim v State of Uttarakhand \& Others (20 March 2017) High Court of Uttarakhand (WPPIL 126/2014) (India).

${ }^{25}$ The Indian case was recognised in recognition of the spiritual relationships of Hindu communities with the river, rather than a specific indigenous or tribal relationship. See O’Donnell (n 3).
} 
legal person. ${ }^{26}$ Further law suits seeking declarations that the Colorado River is a legal person have been filed in October 2017 in the United States. ${ }^{27}$

These cases, although each exists in its own particular social, historical and political circumstances, have been seized by proponents of rights for nature as the embodiment of an ecocentric approach to natural resource regulation. ${ }^{28}$ Proponents of rights for nature believe that giving rivers legal personality reflects their inherent value (not simply as a resource to be exploited) and will enhance the protection of water resources from humans who would do them harm. However, at least in the New Zealand and Colombian contexts, this purported 'ecocentric shift' involving rivers has been largely driven by indigenous and tribal communities, who claim distinct relationships with water based on their cosmovision of guardianship, symbiosis and respect, as opposed to Western liberal utilitarianism. This, within each country's context, suggests that the river person models may in fact be 'anthropocentric'; as an attempt to recognise indigenous and tribal conceptions of the natural world and human relationships with and obligations to nature, raising doubt about the usefulness of the ecocentric/anthropocentric divide.

\section{$<B>2.2 \quad$ Legal personality and legal pluralism}

In this article it is argued that the legal person models used in New Zealand and Colombia should best be understood, not merely as recognition of nature's inherent rights, but as recognition of such rights as an incident of the (human) rights of indigenous and tribal peoples with respect to river territories. The idea that states must 'recognise' indigenous groups, and their ongoing rights to land and resources, the central claim of the international indigenous rights movement, ${ }^{29}$ is inadequately

\footnotetext{
26 Tierra Digna.

${ }^{27}$ Julie Turkewitz 'Corporations have rights. Why shouldn't rivers?' New York Times (26 September 2017) https://www.nytimes.com/2017/09/26/us/does-the-colorado-river-have-rights-a-lawsuit-seeks-todeclare-it-a-person.html.

${ }^{28}$ See eg Laura Villa 'The importance of the Atrato River in Colombia gaining legal rights' (5 May 2017) Earth Law Centre https://www.earthlawcenter.org/new-blog-1/2017/5/the-importance-of-theatrato-river-in-colombia-gaining-legal-rights.

${ }^{29}$ Elizabeth Macpherson 'Beyond recognition: lessons from Chile for allocating indigenous water rights in Australia (2017)' (2017) 40(3) University of New South Wales Law Journal 1130; Glen Sean Coulthard Red Skin, White Masks: Rejecting the Colonial Politics of Recognition (University of Minnesota Press 2014) 1-2; Nancy Fraser 'From redistribution to recognition? Dilemmas of justice in a “post-socialist” age' 1995212 New Left Review 68.
} 
theorised ${ }^{30}$ and ultimately unsettled..$^{31}$ The need for recognition often draws directly or indirectly on theories of 'legal pluralism'; on the basis that indigenous rights and law exist independently of state law and should be recognised by the state. ${ }^{32}$ Recognition is sometimes considered desirable because indigenous peoples have a right to recognition of their distinct cultural identity, or due to their prior or 'first' status as inhabitants of colonised territories. ${ }^{33}$ Such arguments draw on theories of 'reparative justice', which encourage 'amending past wrongs' ${ }^{34}$ and repairing deteriorated relationships between indigenous groups and the state. ${ }^{35}$

Laws that provide for indigenous relationships with natural resources, including for example the common law doctrine of native or aboriginal title, use this terminology of recognition and are typically explained with reference to theories of legal pluralism. ${ }^{36}$ This is the context against which laws that declare rivers as 'legal persons' have developed and, as will be explained here, both the New Zealand and Colombian cases 'recognise' cultural water relationships as reparative solutions to historical injustice involving indigenous (and tribal) groups. Moreover, as well as recognising indigenous relationships with natural resources, the legal person models recognise indigenous jurisdictions: ${ }^{37}$ for the exercise of indigenous management obligations towards the natural world as guardians.

\footnotetext{
${ }^{30}$ Ivison (n 15), 329; Jeremy Waldron 'Why is indigeneity important?' (American Political Science Association 2005) 1, 81-82.

${ }^{31}$ For some examples of different theories of indigenous rights see Brian M Barry Culture and Equality : An Egalitarian Critique of Multiculturalism (Polity 2001); Helen Hughes Lands of Shame : Aboriginal and Torres Strait Islander 'Homelands' in Transition (Centre for Independent Studies 2007); Chandran Kukathas 'Are there any cultural rights?' (1992) 1 Political Theory 105.

${ }^{32}$ Kirsty Gover 'Legal pluralism and state-indigenous relations in Western settler societies' (International Council on Human Rights Policy 2009).

${ }^{33}$ See Will Kymlicka Multicultural Citizenship : A Liberal Theory of Minority Rights (Oxford University Press 1995); Charles Taylor 'The politics of recognition' in Amy Gutmann (ed)

Multiculturalism : Examining the Politics of Recognition (Princeton University Press 1994) 25-33; Karen Engle The Elusive Promise of Indigenous Development : Rights, Culture, Strategy (Duke University Press 2010) 55; James Tully Strange Multiplicity (Cambridge University Press 1995) 184.

${ }^{34}$ See Margaret Urban Walker What Is Reparative Justice? (Marquette University Press 2010) 9.

${ }^{35}$ See Damien Short Reconciliation and Colonial Power : Indigenous Rights in Australia (Ashgate 2008) 15; John Horton 'Political legitimacy, justice and consent' (2012) 15(2) Critical Review of International Social and Political Philosophy 129, 130.

${ }^{36}$ Mabo and Others $v$ State of Queensland (No 2) (1992) CLR 175 (Mabo) 53 (Brennan J); Elizabeth Macpherson Commercial Indigenous Water Rights in Australian Law: Lessons from Chile (PhD Thesis, University of Melbourne 2016) 43-47; Noel Pearson 'The concept of native title at common law' (1997) 5 Australian Humanities Review.

${ }^{37}$ See Jeremy Webber 'Beyond regret: Mabo's implications for Australian constitutionalism' in Duncan Ivison, Paul Patton and Will Sanders (eds) Political Theory and the Rights of Indigenous Peoples (Cambridge University Press 2000) 60, regarding the recognition of indigenous autonomy in the recognition of indigenous title.
} 
However, it is clear from the legal pluralism literature that recognition mechanisms do not preserve indigenous law, or indigenous jurisdictions, in their pristine, pre-contact state, and there is an inevitable process of 'accommodation' in laws that recognise indigenous interests. ${ }^{38}$ They are, as Webber explains, 'mediated rights'. ${ }^{39}$ As a consequence, state laws that provide for indigenous rights are often accused of translating, transforming, and 'essentialising' indigenous interests in order to accommodate them within state law, and failing to account for the continually changing state of indigenous law. ${ }^{40}$ Where states declare rivers as legal persons in New Zealand and Colombia, they are recognising and accommodating indigenous jurisdictions, all the while mediating and limiting indigenous cultures.

\section{Te Awa Tupua: the Whanganui River as a legal person in Aotearoa New}

\section{Zealand}

\section{$<B>3.1 \quad$ Rivers and peoples in Whanganui}

The Whanganui River has always occupied a highly contested space in New Zealand legal and political history. ${ }^{41}$ The Māori who live alongside the river and depend on it for their physical and spiritual sustenance, the Whanganui Iwi, have been concerned about river ownership and management from the onset of British colonisation. When the British acquired sovereignty in New Zealand, with the signing of the Treaty of Waitangi in 1840, Whanganui Iwi became concerned about the British assertion of rights of management and ownership of the river. The first petitions were made by Whanganui Iwi regarding the impact of settlement on their access to and use of the river in the $1870 \mathrm{~s} .{ }^{42} \mathrm{~A}$ series of court cases concerning the river ran from 1938 to 1962 , in what was one of longest pieces of litigation in New Zealand history, during which the Whanganui Iwi consistently maintained that they had rights of ownership and tino

\footnotetext{
${ }^{38}$ See Arif Bulkan 'Disentangling the sources and nature of indigenous rights: a critical examination of common law jurisprudence' (2012) 61(4) International and Comparative Law Quarterly 823, 835.

${ }^{39}$ Webber (n 37) 63-70.

${ }^{40}$ Glen Coulthard 'Subjects of empire: indigenous peoples and the politics of recognition in Canada' (2007) 6(4) Contemporary Political Theory 437, 437; C A Zorzi 'The "irrecognition” of Aboriginal customary law' (2000) 5; Webber (n 37) 64-66; Rutgerd Boelens 'The politics of disciplining water rights' (2009) 40(2) Development and Change 307, 316-20.

${ }^{41}$ See Sanders (n 3).

${ }^{42}$ Waitangi Tribunal 'Whanganui River Report' (Wai 167 1999) 55-56.
} 
rangatiratanga (sovereignty) over the river. ${ }^{43}$ The Iwi were concerned about their continued access to and use of the river for food gathering, navigation and ceremonial uses pursuant to tikanga Māori (customary law). Their concerns exacerbated when settlers began to run steamboats up the river, and use the river for gravel extraction and tourism and later established a major hydroelectric scheme in the river's upper reaches.

The Waitangi Tribunal heard Māori historical claims that the Crown had breached its Treaty obligations in relation to the river in the 1990s, which they reported on in $1999 .{ }^{44}$ Extensive evidence was led before the Tribunal about the river interests of the Whanganui Iwi under tikanga Māori (Māori customary law). In its findings, the Tribunal framed the interests of the Whanganui Iwi in the river in terms of 'ownership'. The Māori interest was 'territorial' in nature as a 'single and indivisible entity' in contrast to western conceptions of property in separate natural resources. The Tribunal explained: 45

<quote>In Maori terms, the Whanganui River is a water resource, a single and indivisible entity comprised of water, banks, and bed. There is nothing unexpected in that. It is obvious that a river exists as a water regime and not as a dry bed. The conceptual understanding of the river as a tupuna or ancestor emphasises the Maori thought that the river exists as a single and undivided entity or essence. Rendering the native title in its own terms, then, what Atihaunui owned was a river, not a bed, and a river entire, not dissected into parts.</quote>

The tribunal's interpretation of Māori rights in the river also incorporated physical as well as metaphysical aspects of a total river territory: ${ }^{46}$

<quote> The river was central to Atihaunui lives, their source of food, their single highway, their spiritual mentor. It was the aortic artery of the Atihaunui heart. Shrouded in history and tradition, the river remains symbolic of Atihaunui identity. It is the focal point for the Atihaunui people, whether living there or away. Numerous marae still line its shores.</quote>

\footnotetext{
${ }^{43}$ See eg In re the Bed of the Wanganui River [1962] NZLR 600.

${ }^{44}$ Waitangi Tribunal (n 42).

45 ibid 337.

${ }^{46}$ ibid xiii.
} 
Almost two decades passed until the Whanganui Iwi reached a political settlement with the Crown for their historical grievances in relation to the river. ${ }^{47}$ However, the negotiations were highly contentious, as under New Zealand common law no one can 'own' water, which is vested in the crown on behalf of the New Zealand public. ${ }^{48}$ The controversy around water ownership is academic, given that the Crown vested the right to use and control water in itself, and allocates rights to take and use water from the river which have many of the incidents of 'property'. Under the Resource Management Act consent authorities, usually local municipal councils, make decisions to grant a 'resource consent' to take and use water on a 'first come, first served' basis. ${ }^{49}$ These consents are temporal, applying only up to 35 years, but they are of immense value, allowing commercial use of and benefit from water, including for activities such as agriculture, tourism and hydropower development.

Thus, the Te Awa Tupua Act is a reparative political settlement to one of New Zealand's longest-running disputes over river management and ownership, as a consequence of historical dispossession, environmental degradation and inequitable development. Sanders has argued that the Te Awa Tupua model is essentially a 'constitution', which restructures the relationship between the Crown and Māori. ${ }^{50}$ This new relationship between Whanganui Iwi and the Crown in the Te Awa Tupua model is made within the reparative justice model arising out of the Treaty of Waitangi. Yet, interestingly, the model is provided for outside of New Zealand's core constitutional documents, such as the New Zealand Bill of Rights Act 1990, ${ }^{51}$ which includes no recognition or protection of the Treaty of Waitangi or its principles, indigenous or cultural rights, or even environmental rights or the rights of nature. ${ }^{52}$

\footnotetext{
47 'Ruruku Whakatupua: Whanganui River Deed of Settlement between the Crown and Whanganui Iwi (March 2014)'.

${ }^{48}$ Water and Soil Conservation Act 1967 (NZ) s 21; Coal Mines Amendment Act 1903 (NZ) s 14;

Water Power Act 1903 (NZ) ss 2, 5; Resource Management Act 1991 (NZ) s 354.

${ }^{49}$ Resource Management Act 1991 (NZ) s 14.

${ }^{50}$ Sanders (n 3) 5, 34.

${ }^{51}$ New Zealand Bill of Rights Act 1990 (NZ).

52 This can be contrasted with the Colombian model, discussed below.
} 
In the New Zealand context, political settlements about rivers (and water more generally) are not new. ${ }^{53}$ The Waitangi Tribunal has inquired into, and the Crown has negotiated and settled, claims to rivers and lakes many times over the past 40 years, including for the Waikato River, which was recognised as a 'living ancestor' and 'indivisible whole' in a similar way to Te Awa Tupua, albeit without legal personality. ${ }^{54}$ Previous river settlements have focused on giving Māori rights of 'co-management', or a right to actively participate in the governance and regulation of rivers, together with the Crown, consistent with the Treaty principle of partnership (a relationship typically described by the Māori concept of 'kaitiakitanga' or guardianship).

However, as will be discussed below, the Te Awa Tupua Act goes further than previous river settlements, and specifically declares that the river is a legal person. Following the recognition of Te Urewera forest as a legal person in the political settlement for another Waitangi Tribunal claim in 2014, ${ }^{55}$ the Te Awa Tupua Act represents a new approach in cultural redress and, ultimately, governance frameworks for natural resources in New Zealand.

\section{$<$ B>3.2 The Te Awa Tupua model}

Rather than treating the river as a resource to be exploited by the people of the Whanganui, the Te Awa Tupua Act positions the Whanganui Iwi as interdependent with and owing responsibilities to the river. Yet, despite the appearance of ecocentrism, the river's rights under the Te Awa Tupua Act are intrinsically tied up with the rights of the Whanganui Iwi and their indigenous cultural 'difference'. ${ }^{56}$

The Te Awa Tupua Act recognises the status of the Whanganui River (and its tributaries) as 'an indivisible and living whole, comprising the Whanganui River from the mountains to the sea, incorporating all its physical and meta-physical elements' ${ }^{57}$ This

\footnotetext{
${ }^{53}$ Jacinta Ruru 'Indigenous restitution in settling water claims: the developing cultural and commercial redress opportunities in Aotearoa, New Zealand' (2013) 2 Pacific Rim Law \& Policy Journal 311, 340; Irons Magallanes (n 9) 309.

${ }^{54}$ Waikato-Tainui Raupatu Claims (Waikato River) Settlement Act 2010 (NZ).

${ }_{55}^{55}$ Te Urewera Act 2014 (NZ).

${ }^{56}$ See Irons Magallanes (n 9) 273; Sanders (n 3).

${ }^{57}$ Te Awa Tupua Act s 12.
} 
framing of Te Awa Tupua comes from the tikanga Māori of the Whanganui Iwi, ${ }^{58}$ and may be contrasted with western, liberal conceptions of natural resources as divisible subjects for propertisation and regulation. Such is apparent from the inclusion of 'metaphysical' elements of the river in its status, together with the physical. As an interesting coincidence, the river's conceptualisation as an 'indivisible and living whole' also aligns with an 'integrated catchment' approach to river regulation, at the entire basin level, now considered to be best practice in water resource management. ${ }^{59}$

The Te Awa Tupua Act then 'declares' that Te Awa Tupua is a 'legal person', which has 'all the rights, powers, duties, and liabilities of a legal person'. ${ }^{60}$ The use of 'declares' here is interesting, as it avoids the use of 'recognises', used in section 12 (when recognising that the river is 'Te Awa Tupua'). In this way the Act recognises the pre-existing status of the river as Te Awa Tupua, but avoids expressly recognising that the river is already (intrinsically or justifiably) a legal person. By using the word 'declares', instead perhaps of the word 'grant', the Act also avoids the other extreme of being seen to confer legal personality on the river, leaving open the possibility that someone might argue that a river may be a person in tikanga Māori regardless of whether or not the state recognises it as such.

As mentioned above, the 'rights powers, duties and liabilities' of a legal person are known to be the rights to sue, be sued, enter into contracts and hold property. Of course, the river itself cannot appear in court or purchase land, so the Te Awa Tupua Act creates a representative, called 'Te Pou Tupua', who must act in the river's interests. The 'office' of Te Pou Tupua established by the Act is the 'human face' of the river to act and speak for and on behalf of Te Awa Tupua, as a river guardian. ${ }^{61}$ One representative is to be nominated by the Crown and the other by the Whanganui Iwi.

The guardian model accords with the ecocentric approach to natural resource management, with Stone having proposed guardians to protect the legal rights of

\footnotetext{
${ }^{58}$ Hutchison (n 14) 180.

${ }^{59}$ Lee Godden 'The role of law at multiple levels' in Janice Gray, Cameron Holley and Rosemary Rayfuse Trans-jurisdictional Water Law and Governance (Earthscan 2016) 27-28.

60 Te Awa Tupua Act s 14.

61 ibid ss $18-19$.
} 
nature. ${ }^{62}$ However, in New Zealand's indigenous rights context, use of the guardian model is a typical implementation of the principles of kaitiakitanga and partnership with Māori under the Treaty of Waitangi. ${ }^{63}$ The guardianship model adopted in Te Pou Tupua certainly goes further than the previous applications of the treaty principles of kaitiakitanga and partnership in co-management arrangements for natural resources, in which central government or local/regional authorities share public administration of natural resources with Māori groups. ${ }^{64}$ Te Pou Tupua gives Māori a stronger role in river management, and in this sense goes further to recognise Māori rights of tinorangatiratanga or self-government, ${ }^{65}$ as an equal guardian partner. The two guardians, former Member of Parliament Dame Tariana Turia and educator Turama Hawira, were appointed in September 2017 and hold office for three years. ${ }^{66}$ Interestingly, neither of the guardians currently works for the Crown and both have links to the Whanganui, suggesting the importance of a perception of legitimacy for the appointment of river guardians as having local, indigenous expertise and authority.

Te Pou Tupua has broad powers although it must act in the interests of the river and consistently with prescribed values for the river's management. These values (called 'Tupua te Kawa') are set out in section 13 of the Act, described as the 'intrinsic values that represent the essence of Te Awa Tupua'. These values are highly significant as they help us to understand the content of the river's rights. ${ }^{67}$ Administrative decision makers under a range of legislation affecting river regulation (including, notably, the Resource Management Act 1991) must recognise, provide for and have regard to the status of Te Awa Tupua as a legal person and the statutory river values, as a 'relevant consideration'. ${ }^{68}$ However, the Te Awa Tupua Act acknowledges that decisions made under other legislation must be exercised consistent with the purpose of that legislation

\footnotetext{
${ }^{62}$ Stone (n 11).

${ }^{63}$ Irons Magallanes (n 9) 281.

${ }^{64}$ See eg Waikato-Tainui Raupatu Claims (Waikato River) Settlement Act 2010 (NZ); Resource

Management Act 1991 (NZ) ss 6, 7 and 8 and the new Mana Whakahono ā Rohe arrangements under ss 58O-58U.

${ }^{65}$ Such rights are reflected in the guarantee of tino rangatiratanga under art 2 of the Treaty of Waitangi.

${ }^{66}$ Zaryd Wilson 'Whanganui River representatives appointed' NZ Herald (5 September 2017) http://www.nzherald.co.nz/nz/news/article.cfm?c_id=1\&objectid=11916893.

${ }^{67}$ Good (n 8) 35-36. Good discusses the difficulty, once rights for nature are recognised, of determining the content of such rights in the absence of the river's ability to speak for itself. ${ }^{68}$ Te Awa Tupua Act s 15.
} 
and neither Te Awa Tupua status nor Tupua te Kawa can be determining factors in an administrative decision, ${ }^{69}$ engendering a perception of 'rubber stamping'.

The statutory river values, 'Tupua te Kawa', acknowledge the river as a source of spiritual and physical sustenance, feeding the resources within it and people living alongside it. ${ }^{70}$ They recognise the direct link between the health of the river and the health of the people, reflecting evidence presented before the Waitangi Tribunal leading up to the settlement of contamination of river health and spirituality negatively affecting the health of the people. ${ }^{71}$ The values reiterate that the river is an indivisible and living whole from the mountains to the sea incorporating physical and metaphysical elements. They also acknowledge responsibility of the Whanganui Iwi for the river's health (guardianship), that the large and small streams form one river (integrated catchment management), and the common purpose of all elements and entities in the river working towards the river's health and wellbeing (collaborative governance).

Finally, the Te Awa Tupua Act establishes a complicated, collaborative governance regime for the river between Māori, municipal and central government and private users. ${ }^{72}$ In this regime a range of entities are created, and a range of perspectives covered, not just those of Te Pou Tupua or the Whanganui Iwi. These are: 'Te Karewao', an advisory group to Te Pou Tupua consisting of representatives of Māori river communities and authorities and relevant local authorities; ${ }^{73}$ 'Te Kōpuka', a collaborative strategy group for Te Awa Tupua comprising representatives of persons and organisations with interests in the Whanganui River, including iwi, relevant local authorities, departments of State, commercial and recreational users, and environmental groups $;{ }^{74}$ and 'Te Heke Ngahuru', a strategy for the collaboration of persons with interests in the Whanganui River, in order to address and advance the health and wellbeing of Te Awa Tupua. ${ }^{75}$

\footnotetext{
${ }^{69}$ ibid s 15(5).

70 ibid s 13(a).

${ }^{71}$ Waitangi Tribunal (n 42) 79.

${ }^{72}$ See Sanders (n 3) 30. For a discussion of collaborative governance see Cameron Harrington 'The political ontology of collaborative water governance' (2017) 42(3) Water International 254.

73 Te Awa Tupua Act s 27.

74 ibid s 29.

75 ibid s 35 .
} 
How, exactly, the various governance arrangements will operate in practice is yet to be seen, as the surrounding policy framework has not been fully developed and some of the governance bodies are yet to be established. However, New Zealand's natural resources planning framework is undoubtedly significantly affected by the Te Awa Tupua Act in Whanganui River territory, and there are 24 cross references from the Te Awa Tupua Act to the Resource Management Act 1991. These include that Te Awa Tupua is to be treated as a public authority for the purposes of the Resource Management Act $1991 .^{76}$ Notably, the consent of Te Pou Tupua is not required for applications for resource consent to use the river's water under the Resource Management Act 1991 (its consent is required to use the river bed), although a consent authority may determine that Te Pou Tupua is an 'affected person' ${ }^{77}$ Interestingly, even if Te Pou Tupua as an 'affected person' gives its consent to certain activity being carried out on the river the consent authority cannot disregard any effect of that activity on the river. ${ }^{78}$ This is a protection of the river's interests over and above the guardianship of Te Pou Tupua, reinforcing the model's ecocentric themes.

What the Te Awa Tupua Act does not do is impact in any way on property interests in the river. The settlement is the culmination of more than a century of indigenous agitation for the right to 'own' the river, always resisted by the Crown on the basis that 'no one can own water'. Under the Act only the Crown-owned parts of the bed of the river is vested in Te Awa Tupua, and the settlement has no impact on public rights of use, fishing or navigation or private consents or permits to use the river, in a provision that specifically protects the rights of hydro-electric power generators as state-owned enterprises and mixed use model companies. ${ }^{79}$ In this way, the Te Awa Tupua Act follows the approach taken in a number of earlier settlements, which vested the beds of rivers and lakes in Māori groups and focused on co-management.

\section{<A>4 El Río Atrato: the Atrato River as a legal person in Colombia}

\section{$<B>4.1 \quad$ Rivers and peoples in Chocó}

\footnotetext{
76 ibid s 17.

${ }^{77}$ Resource Management Act 1991 (NZ) s 46(3).

${ }^{78}$ Te Awa Tupua Act s 63.

${ }^{79}$ Resource Management Act 1991 (NZ) ss 41, 46.
} 
The Atrato River is located in Colombia's poorest and most forgotten region of Chocó. ${ }^{80}$ Running along the Pacific Coast of Colombia, Chocó is a place of rich natural resources and biodiversity and also, paradoxically, has been a site for conflict and contestation. In Chocó, almost half of the population lives in extreme poverty and the region has been ravaged by the internal war, plagued by the drug trade, and caught in the path of organised crime. The government of Colombia has not, historically, had a strong presence in Chocó, and its impoverished constituents face a daily struggle to meet their basic human needs. The reasons for Chocó's plight have deep roots in Colombia's colonial past. As Colombian researcher Jaime Bonet has pointed out, there are at least four key factors contributing to the crisis in Chocó: (i) a colonial legacy characterised by weak or inexistent political and administrative institutions; (ii) challenging geographic conditions and poor communication and access; (iii) an extractive economic structure based on the exploitation of natural resources (specially gold mining) for more than three centuries, and (iv) a complete isolation of the region from the country. ${ }^{81}$

Chocó is also an ethnically and socially particular part of Colombia: 97 per cent of the population belongs to an indigenous or Afro-Colombian community ${ }^{82}$ The ethnic communities occupy 'ancestral' territories, called resguardos (in the case of indigenous people) and consejos mayores (in the case of Afro-Colombian communities), practicing traditional forms of life including artisan mining of gold and silver, traditional agriculture, hunting and fishing, with which they have supported themselves for centuries. ${ }^{83}$ The Afro-descendant communities of Chocó were brought by the Spanish from Africa in the process of colonisation to boost the slave economy, replacing the 'weak' and 'sick' indigenous workforce. Their first task was to extract gold from the Santa María de la Antigua del Darién mine in northern Chocó in $1510 .{ }^{84}$ These communities enjoy a particular symbiosis with the indigenous communities, living off

\footnotetext{
${ }^{80}$ The Chocó region (Departamento de Chocó) has an extension of nearly 46,530 square kilometres. Chocó also has 30 'municipios' (municipalities) in 5 sub-regions: Atrato, San Juan, Pacífico Norte, Baudó (Pacífico Sur) and Darién. Departamento Nacional de Estadística, 'Censo General 2005: "Proyecciones Nacionales y Departamentales de Población 2005-2020"” (2010).

${ }^{81}$ Jaime Bonet ¿¿Por qué es pobre el chocó? Documentos de Trabajo Sobre Economía Regional' (90, Banco de la República, Bogotá, Centro de Estudios Económicos Regionales 2007).

${ }^{82}$ Departamento Nacional de Estadística (n 80).

${ }^{83}$ Jaime Bonet (n 81); Tierra Digna 2.

${ }^{84}$ Robert C West La Minería de Aluvión En Colombia Durante El Período Colonial (Imprenta Nacional de Colombia 1972).
} 
the land and taking only limited part in mainstream Colombian society. The Afrodescendant communities are contemplated by the concept of 'tribal' peoples, under the International Labour Organisation's Convention No 169 Concerning Indigenous and Tribal Peoples in Independent Countries ${ }^{85}$ At a domestic level, the Colombian Constitutional Court has recognised the special character of the Afro--descendant communities (which they classify as 'multiethnic and multicultural') as a part of the social and ethnic diversity of the Colombian nation, of equal status to any other ethnic community. ${ }^{86}$

The Atrato River, the longest and third most navigable in the country, winds its way $750 \mathrm{~km}$ through Chocó from the Andes mountains (Cerro Plateado) to the gulf of Urabá in the Caribbean Sea. The river is part of a massive basin covering 40,000 square kilometres and 60 per cent of Chocó is fed by more than 15 rivers and 300 streams. ${ }^{87}$ The people of Chocó who live alongside the Atrato River, much like the Whanganui Iwi in New Zealand, depend on the river for their physical, cultural and spiritual sustenance. ${ }^{88}$ They claim to have relationships with the Atrato basin not just as their ancestral territory, but as a 'space to reproduce life and recreate culture'. ${ }^{89}$ For the Atrato communities the river is everything. It is their way of measuring time, the place where children play and learn how to swim, and the only highway to other parts of the region..$^{90}$

Chocó is considered to be 'mega-biodiverse'; one of the most biodiverse places on the planet with 90 per cent of the region being protected forest area. ${ }^{91}$ There is also gold and silver in the river and artisanal mining has been practised in the region for many years (including by some Afro-descendant and indigenous communities). However,

\footnotetext{
${ }^{85}$ Convention Concerning Indigenous and Tribal Peoples in Independent Countries (No 169) (1989) 28 ILM 1382 (entered into force 5 September 1991) (Convention 169) 169.

${ }^{86}$ Consejo Comunitario Mayor Cuenca Río Cacarica v Ministry of Environment and Others No T-955 of 2003, Corte Constitucional [Constitutional Court], Sala Octava de Revision [Eighth Chamber] (Colombia) (17 October 2003) 81.

${ }^{87}$ Tierra Digna 2-3; Juan Carlos Bello Atlas de La Biodiversidad de Colombia (Instituto Alexander von Humboldt 2000).

${ }^{88}$ Camilo Antonio Hernandez Ideas y Practicas Ambientales del Pueblo Embera del Chocó (Cerec 1995) 12.

${ }^{89}$ Tierra Digna 165.

${ }^{90}$ Acta Final de Inspección Judicial, Appendix 1, Part B in Tierra Digna.

${ }^{91}$ Juan Carlos Bello (n 87). Ley 2 de 1959 'Por la cual se dictan normas sobre economía forestal de la Nación y conservación de recursos naturales renovables’.
} 
since the 1990s, mechanised illegal mining and logging (without permit or concession from the state or the communities) has intensified along the river. The illegal mines dotted along the Atrato use dredges (called dragas y dragones by locals) and excavators in their activities, often operated by armed organised criminals (including guerrilla groups such as the extinct FARC-EP, and active organisations: ELN, paramilitary structures and drug dealers of the 'Clan del Golfo'). ${ }^{92}$ The operators also use mercury and cyanide to assist the mining process.

These activities have caused extreme degradation of the Atrato River. They have destroyed the natural course of the river and flooded the rainforest in many parts, and the river has become massively contaminated with dangerous chemicals killing fish and vegetation. The impact of this activity on the environmental condition of the river and the river relationships of the Atrato communities has been catastrophic. The Atrato people have suffered as the chemicals make their way into the food chain, traditional subsistence practices are disrupted and communities are displaced. All of this has occurred under the complacency of central government, regional and local authorities in Colombia, all of which have turned a blind eye to the environmental and humanitarian consequences. The Court calls this 'a humanitarian, social and environmental crisis without precedent'. ${ }^{93}$

In contrast to New Zealand, the protection of the environment, including indigenous relationships with natural resources, has constitutional status in Colombia. ${ }^{94}$ In fact, the protection of the environment is a founding principle of the core-concept of the Colombian Constitution, known as the Estado social de derecho. Since 1991, the Colombian Constitution has specifically provided for la Constitución Ecológica (the Ecological Constitution); a series of provisions intended to protect environmental

\footnotetext{
${ }^{92}$ César Rodriguez Garavito Etnicidad.Gov: Los Recursos Naturales, Los Pueblos Indígenas y El Derecho a La Consulta Previa En Los Campos Sociales Minados [Natural Resources, Indigenous Peoples and the Right of Prior Consultation in Mining Territories] (Centro de Estudios de Derecho, Justicia y Sociedad, Dejusticia 2012) 6-9; Alfredo Molano Bravo De Río En Río: Vistazo a Los Territorios Negros (Editorial Aguilar 2017).

${ }^{93}$ This investigation is documented by the Ombudsman Office of Colombia. Defensoría del Pueblo. "Crisis humanitaria en el Chocó: diagnóstico, valoración y acciones de la Defensoría del Pueblo" Bogotá (2014); “Resolución Defensorial 064 de 2014” Bogotá, Septiembre 2014; Tierra Digna 109. ${ }^{94}$ The 'Ecological Constitution' is integrated for more than 30 provisions (from preamble to article 366) in a double dimension: (i) integral protection of the environment and (ii) guarantee of a sustainable development.
} 
interests including both rights and obligations. ${ }^{95}$ In particular, Articles 79 and 80 recognise the collective right of all people to a healthy environment and the responsibility of the State to protect the diversity and integrity of the environment, conserve areas of special ecological importance, plan the management and use of natural resources to guarantee their sustainable development, conservation, restoration or substitution and prevent and control environmental deterioration. ${ }^{96}$ The Ecological Constitution has provided fertile ground for the reconceptualisation of natural resources such as rivers as legitimate rights-bearing entities in Colombia, ${ }^{97}$ and the recognition of the particular relationships indigenous communities hold with the natural world. ${ }^{98}$

\section{$<B>4.2 \quad$ The Atrato model}

The Río Atrato case was brought in the Constitutional Court in early 2015 by the human rights NGO Tierra Digna on behalf of a number of Indigenous, Afro-descendant and peasant communities in Chocó. ${ }^{99}$ The case was an 'acción de tutela' under article 86 of the Colombian Constitution for protection of the constitutional rights of the river communities, who argued that the activities of illegal miners in Chocó violated their fundamental rights to life, health, water, food security, healthy environment, culture and territory under the Constitution. Article 86 allows all Colombians to apply to any judge in the country or the Constitutional Court for an order for protection of their fundamental rights when they are vulnerable or threatened by an act of omission of a public or private authority.

\footnotetext{
${ }^{95}$ See Oscar Darío Amaya Navas La Constitución Ecológica de Colombia: Análisis Comparativo Con El Sistema Constitucional Latinoamericano (Universidad Externado de Colombia 2002).

${ }^{96}$ See also arts 1, 2, 8, 49, 79, 86, 88, 95, 333 and 366.

${ }^{97}$ An earlier case on river rights, although not adopting the concept of legal personality is the case of the Rio Bogota, in which the Council of State also made a series of very prescriptive orders in response to serious environmental contamination of the river. Consejo de Estado, Sala de Contencioso Administrativo, Sección Primera, 28 de Marzo 2014. See Luis Felipe Guzmán Jiménez Las Aguas Residuales En La Jurisprudencia Del Consejo de Estado: Periodo 2003-2014 [Wastewater in the Jurisprudence of the Administrative Court of Colombia: 2003-2014] (Universidad Externado de Colombia 2015) 18.

${ }^{98}$ Article 330 of the Colombian Constitution creates the indigenous territories ('resguardos indigenas') based on customary and ancestral indigenous law.

99 The Centro de Estudios para la Justicia Social 'Tierra Digna' represented the following river communities: Consejo Comunitario Mayor de la Organización Popular Campesina del Alto Atrato (Cocomopoca), el Consejo Comunitario Mayor de la Asociación Campesina Integral del Atrato (Cocomacia), la Asociación de Consejos Comunitarios del Bajo Atrato (Asocoba), el Foro Inter-étnico Solidaridad Chocó (FISCH).
} 
In its decision, the Court found that the government had violated all of the fundamental constitutional rights alleged to have been breached by the communities through its omission to control and eradicate illegal mining in Chocó. Then, significantly, the Court recognised that the Atrato River (together with its basin and tributaries) is an entidad sujeto de derechos (legal person). The Court did so with reference to the Whanganui River settlement in New Zealand, along with the Constitutions of Ecuador and Bolivia. The Court determined that the river's rights (distinct from the communities' rights) are to protection, conservation, maintenance and restoration by the State and ethnic communities.

The Court then made several prescriptive orders to implement its decision, including that the rights of the river will be represented by a guardian, with one representative from government and one from the claimant communities, much like the Te Awa Tupua model from New Zealand. The Court gave the President and the communities one month to each choose their representative, however, the 15 river guardians were eventually all appointed by the last week of August 2017. The President's named representative is the Ministry for the Environment and Sustainable Development. ${ }^{100}$ The seven river communities each appointed one male guardian and one female guardian to ensure gender equality, ${ }^{101}$ another interesting manifestation of the importance of representative legitimacy for guardians within indigenous and Afrodescendant communities.

The judgment ordered the guardians to design and form a 'commission of guardians of the Atrato river' (within three months), involving the designated guardians plus an 'advisory group' including the NGOs Humboldt Institute and WWF Colombia, both of whom developed a project for the protection of the river Bita in another part of the country (Vichada, Orinoquía region). This advisory group is similar in many respects to Te Karewao and Te Kōpuka for the Whanganui River. Even more interesting, the Court designed a special interdisciplinary-body to verify and evaluate the proper

\footnotetext{
${ }^{100}$ Ministerio de Ambiente y Desarollo Sostenible [Ministry for the Environment and Sustainable Development], 'Decreto No. 1148 Por el cual se designa al representante de los derechos del Río Atrato en cumplimiento de la Sentencia T-622 de 2016 de la Corte Constitucional [Decree No 1148 Designating the Representative of the Rights of the Atrato River Giving Effect to Sentence T-622 of 2016 of the Constitutional Court] art 1.

${ }^{101}$ Heinrich-Böll-Stiftung Todas y Todos Somos Guardianes Del Atrato! https://co.boell.org/es/2017/09/04/todas-y-todos-somos-guardianes-del-atrato.
} 
execution of the orders called panel de expertos (expert commission) headed by the main public sector regulation body in the country, the Procuraduría General de la Nación. This panel is comprised of several experts from ethnic communities and public, private, academic and social (NGO) organisations to ensure that the Court's orders are carried out correctly and in due time.

The judgment also includes orders requiring a number of government departments and entitles and universities to get together to design and implement a plan to decontaminate the river. ${ }^{102}$ This order is similar to the collaboration of persons with interests in the Whanganui River in order to address and advance the health and well-being of Te Awa Tupua contemplated by the strategy Te Heke Ngahuru. Other orders require other government bodies, including the police, military and Ministry of Defence to develop a plan to neutralise and permanently eradicate illegal mining in Chocó. Finally, the judgment includes orders intended to support the recuperation of traditional forms of subsistence and food and further research into the effects of the contamination. Key to every part of the Atrato model is the Court's requirement for mandatory participation of the ethnic communities at every step of design and execution of the orders.

This 163-page decision of the Constitutional Court of Colombia is a watershed moment for indigenous and environmental rights in Latin America. The deep theoretical reasoning of the Court in the decision is beautiful, and reflects the involvement of human rights NGOs and academics in the case. The Court engages with a long line of Colombian jurisprudence on indigenous, Afro-descendant and environmental rights. These include cases where the Constitutional Court has protected the collective rights of ethnic communities to survive, to have a territory, to manage natural resources for legal autonomy, to be consulted (ILO 169), to participate in development projects and to enjoy a healthy environment. These cases rely upon the Ecological Constitution, and the guarantee of human dignity (vida digna), common welfare (bienestar general) and social justice ('justicia social'); three concepts that are at the core of the Colombian constitutional model: el Estado social de derecho (a state of 'social development').

102 Tierra Digna 159. 
Yet, interestingly, the Court draws heavily on conceptions of indigenous resource rights in international law and jurisprudence of the Inter-American Court of Human Rights. In arriving at legal personality for the river the Court relies on concepts of indigenous and environmental rights in ILO Convention No $169,{ }^{103}$ United Nations Declaration on the Rights of Indigenous Peoples, ${ }^{104}$ the Convention on Biodiversity, ${ }^{105}$ the American Declaration on the Rights of Indigenous Peoples, ${ }^{106}$ the UNESCO Convention on intangible property ${ }^{107}$ and the human right to water, ${ }^{108}$ before discussing leading cases Sawhoyamaxa v Paraguay, ${ }^{109}$ Awas Tingni, ${ }^{110}$ Saramaka v Suriname. ${ }^{111}$ The Court's outward looking approach to Colombian constitutional development also references domestic comparative law from within and beyond the Latin American civil law perspective including the Whanganui River and Te Urewera in New Zealand, and rights for nature in Ecuador and Bolivia. This 'internationalisation' of rights for nature in the Atrato decision is interesting, given the relative silence from international law on the topic of legal rights for rivers.

The Court explicitly recognises that it is taking an 'ecocentric' approach in its analysis, referring to the interconnectedness of humans with nature, the superior interest of the environment, and human obligations to protect nature's rights. In this sense the Court explains: ${ }^{112}$

<quote>Nature and environment is a cross-cutting theme in the Colombian constitutional order. Its importance is obviously due to the human beings who inhabit it and the need to have a healthy environment to lead a dignified life in conditions of

\footnotetext{
${ }^{103}$ ILO Convention Concerning Indigenous and Tribal Peoples in Independent Countries 169 (ILO Convention No 169).

${ }^{104}$ United Nations General Assembly Declaration on the Rights of Indigenous Peoples A/RES/61/295 (13 September 2007).

${ }^{105}$ Convention on Biological Diversity (opened for signature 5 June 1992) 1760 UNTS 79 (entered into force 29 December 1993) (Convention on Biological Diversity).

${ }^{106}$ Inter-American Commission on Human Rights (IACHR) 'American Declaration on the Rights of Indigenous Peoples'.

${ }^{107}$ UNESCO Convention for the Safeguarding of the Intangible Cultural Heritage

MISC/2003/CLT/CH/14 (adopted 17 October 2003).

108 'United Nations Resolution on the Human Right to Water and Sanitation GA Dec 64/292, 64th Sess, 108th Plen Mtg UN Doc A/RES/64/292 (28 July 2010)'.

${ }^{109}$ Sawhoyamaxa v Paraguay IACHR Series C No 146 (29 March 2006) (Sawhoyamaxa v Paraguay).

${ }^{110}$ The Mayagna (Sumo) Awas Tingni Community v Nicaragua IACHR Series C No 79 (31 August 2001) (Mayagna v Nicaragua).

${ }^{111}$ Saramaka People v Suriname (Preliminary Objections, Merits, Reparations, and Costs) IACHR Series C No 172 (28 November 2007).

112 Tierra Digna 42.
} 
well-being, but is also for the other living organisms with which the planet is shared, understood as entities worthy of protection in of themselves. This means being conscious of the interdependence that connects all living things on the Earth; that is, to recognise that we are integral parts of the global ecosystem and biosphere, before applying normative categories of domination, simple exploitation or utility.</quote>

However, the decision is 'anthropocentric' in the sense that the river's rights are incidental to the recognition of the communities' human rights and this case is inherently tied up with the ancestral, territorial, communal and 'biocultural rights ${ }^{\text {'113 }}$ of the ethnic communities. The Court goes on to say: ${ }^{114}$

<quote> This approach has a special relevance in Colombian constitutionalism, keeping in mind the principle of cultural and ethnic pluralism that supports it, together with the ancestral knowledge, use and customs of indigenous and tribal peoples. Accordingly, in the following paragraph we explore an alternative vision of the collective rights of the ethnic communities in relationship to their cultural and natural surroundings, which are called, 'biocultural rights'. </quote>

The Constitutional Court recognises the inescapable connection between the rights of nature and the rights of humans as biocultural rights, the basis of which is the "profound unity between nature and the human species'. ${ }^{115}$

The detail and strength of the orders in the Atrato case demonstrate a certain judicial activism to obligate the executive branch of government to take action to respond to the serious environmental and humanitarian crisis in the river territory. This is particularly interesting because the government had no hand in the contamination, and only acted by omission. However, is the duty of the Colombian State (and not just the current

\footnotetext{
113 The term 'biocultural rights' denotes a community's long-established right, in accordance with its customary laws, to steward its lands, waters and resources. Such rights are being increasingly recognised in international environmental law. Biocultural rights are not simply claims to property, in the typical market sense of property being a universally commensurable, commodifiable and alienable resource; rather, biocultural rights are collective rights of communities to carry out traditional stewardship roles vis-à-vis nature, as conceived of by indigenous ontologies. See K Bavikatte and T Bennett 'Community stewardship: the foundation of biocultural rights' (2015) 6(1) Journal of Human Rights and the Environment; Gabriel Nemogá 'Limitada protección de la diversidad biocultural de la nación' in Encuentro Constitucional por la Tierra (2014).

114 Tierra Digna 42.

115 ibid 47; Bavikatte and Bennett (n 113); Nemogá (n 113).
} 
government) to ensure a plural society based on the respect of ethnic communities and the implementation of the concept of Estado social de derecho taking into account: (i) the diversity of cultures, races and ethnic identities that coexist in the country; (ii) the guarantee of equal rights and respect for everyone; (iii) the fact that the ethnic communities are part of the Colombian nation as pre-existing tribes and, (iv) importantly, the right of indigenous and Afro-descendant communities to have a territory and a life with justice and dignity.

\section{$<$ A $>5$ River persons in context}

\section{$<B>5.1 \quad$ The rights of people versus the rights of nature}

Much has been made of the ecocentric qualities of legal person models, in prioritising the rights of nature over the rights of people. However, the idea of rivers as legal persons in both New Zealand and Colombia, although emerging from and existing within very different circumstances, is more helpfully understood with reference to legal and cultural pluralism. ${ }^{116}$ In each country, legal personality is a mechanism adopted by the state to recognise river interests and relationships existing in indigenous and tribal customs and laws. This approach may have limitations, including the risk of 'essentialising' indigenous culture in a pristine, tribal, subsistence, environmental, or pre-contact light, ${ }^{117}$ and leaving open the question whether the rights of nature can exist outside of such a cultural context. The approach may also create tensions with the idea of 'ethno-development', which has underpinned indigenous activism at a regional level in Latin America, and promotes alternative models of indigenous economic development. ${ }^{118}$

\footnotetext{
116 The development of the rights of nature in Ecuador and Bolivia has also occurred within a context of legal and cultural pluralism, via the concept of buen vivir - to live a good life. See generally Tom Perreault 'Tendencies in tension: resource governance and social contradictions in contemporary Bolivia' in Lori Leonard (ed) Governing Resource Extraction (Routledge 2017); Craig M Kauffman and Pamela L Martin 'Can rights of nature make development more sustainable? Why some Ecuadorian lawsuits succeed and others fail' (2017) 92 World Development 130.

${ }^{117}$ See above for a discussion of the risk of essentialising indigenous culture in the legal pluralism literature.

${ }^{118}$ See Engle (n 33). Note that the Constitutional Court in the Atrato case actually refers to the idea of ethno-development in support of its approach. Tierra Digna 155.
} 
The idea of extending legal personality to the Whanganui River cannot be divorced from its cultural context, as part of a political settlement with Whanganui Iwi intended to repair past wrongs and recognise Māori relationships with water. ${ }^{119}$ The Te Awa Tupua model reflects the conceptualisation of the relationship between humans and the natural world in the tikanga (law) of the Whanganui Iwi. ${ }^{120}$ According to their tikanga, the river has rights to which the Iwi belong and not the other way round, exemplified in the Iwi's idiom: 'I am the river, and the river is me'.

The Constitutional Court of Columbia's recognition of the 'biocultural' rights of the Atrato communities also highlights the role of legal and cultural pluralism in the legal person idea. The Court frames the ethnic communities' rights as the right 'to administer and exercise trusteeship in an autonomous manner over their territories - in accordance with their own laws and customs'. ${ }^{121}$ The Court points out that these 'biocultural rights' 'are not new rights for the ethnic communities', but rather a category that unifies their interconnected rights in natural resources and to culture. ${ }^{122}$ This conceptualisation resembles recognition models including native or aboriginal title, where state law recognises and gives effect to pre-existing indigenous laws and customs. ${ }^{123}$

Both the Colombian and New Zealand models are therefore anthropocentric in the sense that they create new relationships between the state and communities, ${ }^{124}$ in recognition of the culturally-specific guardianship relationship between communities and nature. However, it is clear from the legal pluralism literature that when states 'recognise' indigenous rights and interests, there is an inevitable process of translation, accommodation and mediation. ${ }^{125}$ Legal personality is a mechanism used to recognise indigenous and tribal relationships and jurisdictions to manage the natural world. However, the jurisdiction is not recognised in its complete form, and is actually limited under the process of recognition.

\footnotetext{
${ }^{119}$ See Irons Magallanes (n 9) 325-26; Sanders (n 3).

${ }^{120}$ Sanders (n 3) 4.

121 Tierra Digna 43.

122 ibid 44.

${ }^{123}$ See above.

124 See Sanders (n 3) 34.

125 See above.
} 
The claims made by Māori to the Whanganui River had always been framed as rights of 'ownership', and the Waitangi Tribunal inquiring into those claims did not mention 'rights for nature' or 'legal personality'. It framed Māori interests in the river under tikanga Māori as 'proprietary' and 'territorial' rights to the entire catchment and all its resources based on ancestry. ${ }^{126}$ However, in the political compromise that is the Te Awa Tupua Act, no one has the right to 'own' the river as a whole. ${ }^{127}$ The failure to give the river the legal right to its own water creates a paradox. How can Te Awa Tupua be an 'indivisible and living whole from the mountains to the sea incorporating physical and metaphysical elements' ${ }^{\prime}{ }^{128}$ and yet carved up into different proprietary regimes for the bed, water, wildlife etc? How can the Te Awa Tupua Act be put forward by some proponents as illustrative of the dichotomy between property in nature and rights for nature, ${ }^{129}$ when the model has no impact on underlying (and overlapping) legal rights regimes? ${ }^{130}$

The Te Awa Tupua Model, at once recognising and limiting an indigenous jurisdiction, is simply an advanced collaborative governance approach, in which the interests of the river are emphasised in its regulation by the government, Māori and other community and business interests. As Sanders rightly points out, the legal person model is a new 'constitutional' framework to 'regulate human relationships' and establish a forum for disagreement and compromise: recognising the competing claims of the crown and Māori to political authority. ${ }^{131}$

In Colombia, while the Atrato communities' biocultural rights are positioned as being territorial in nature, ${ }^{132}$ and although the indigenous and Afro-descendant communities successfully claimed a failure to protect their right to 'territory', the Court does not recognise a right of property for the communities in the river, nor for the river to own

\footnotetext{
${ }^{126}$ Waitangi Tribunal (n 42) 337, 343.

${ }^{127}$ Laura Hardcastle 'Turbulent times: speculations about the Whanganui River's position as a legal entity’ (2014) Maori Law Review http://maorilawreview.co.nz/2014/02/sir-edward-taihakurei-duriestudent-essay-competition-2013-turbulent-times-speculations-about-the-whanganui-rivers-position-asa-legal-entity/; Sanders (n 3) 28-29.

128 Te Awa Tupua Act s 12.

${ }^{129}$ Hutchison (n 14); Margil (n 14) 8.

${ }_{130}$ Macpherson and O’Donnell (n 3).

${ }^{131}$ Sanders (n 3) 1.

132 Tierra Digna 45, 48-56.
} 
itself. In this regard the Atrato case, like that of the Whanganui River is much more about water governance than it is about water property.

The Colombian case emerges squarely from the strong constitutional protection of indigenous and environmental rights, and a rich national and international jurisprudence regarding indigenous rights to natural resources in Latin America. The case is, therefore, underpinned by the fundamental rights people have with respect to the natural world, and the Constitutional Court of Colombia uses human rights protections (the right to life, to water, to live in a clean environment, etc) to reach its result. The Court is developing rights for nature in the Colombian constitutional context as an extension of human rights law, similar to the way in which Latin American cases have used the protection of indigenous 'territory' by expanding the right to 'property'. ${ }^{133}$ It even refers to the rights of nature as the 'third generation' of human rights, after civil and political and then economic social and cultural rights. ${ }^{134}$

In the New Zealand context, the Te Awa Tupua model does not rest on core constitutional human rights documents, although as part of the Treaty of Waitangi reparative framework, it certainly shows how human rights doctrine develops (arguably more effectively) outside of core human rights laws. The extension of the human rights paradigm in both Colombia and New Zealand further highlights the simplicity of the traditional dichotomy of an earth versus human centred model.

$<B>5.2 \quad$ Institutions and enforceability

Enforcing rights for nature has been problematic in comparative contexts. In Ecuador, for example, protections of the rights of nature (and the concept of buen vivir) have been erratically implemented by courts, ${ }^{135}$ and are often described as 'weak', although they are gradually having greater policy impact in decision-making processes. ${ }^{136}$ The

\footnotetext{
${ }^{133}$ See eg Mayagna $v$ Nicaragua.

${ }^{134}$ Tierra Digna 137.

${ }^{135}$ Mary Elizabeth Whittemore 'Problem of enforcing nature's rights under Ecuador's constitution: why the 2008 environmental amendments have no bite' (2011) 3 Pacific Rim Law and Policy Journal 659 .

${ }^{136}$ Craig M Kauffman and Pamela L Martin, 'Can Rights of Nature Make Development More Sustainable? Why Some Ecuadorian Lawsuits Succeed and Others Fail' (2017) 92 World Development $130,138$.
} 
broad protection of the rights of Mother Earth in Bolivia, too, has had little practical impact in preventing environmentally damaging development. ${ }^{137}$ It is too early to tell how river rights will be upheld in the New Zealand and Colombian cases, however, their architects have clearly given more thought to the challenges of implementation and enforceability in both approaches.

The adoption of legal personality as a model for recognising rights of natural resources is itself a response to the problem of enforceability. The Ecuadorian and Bolivian models have been erratic in their implementation because it is not clear who has standing to take action to uphold nature's rights. Both the Whanganui and Atrato models tackle this ambiguity head on, and rather than simply recognising that rivers can be rights-bearing, the institution of the legal person is created, and the rights attach to the institution as a person. As a legal person a river can take legal action in its own name if necessary to respond to environmental threat or promote environmental outcomes. Te Awa Tupua, for example, might assert its interests as a legal person in the future by applying for a water conservation order under Part 9 of the Resource Management Act 1991 to protect the river. If the Colombian government fails to stamp out illegal mining, the guardians of the Río Atrato might return to the Constitutional Court on the river's behalf.

Much more significant than the creation of the legal fiction of personality for rivers, is the institutional framework accompanying it to protect and manage river rights by partnership, consensus and collaboration. The Atrato case engages directly with the difficulty of enforcing the rights of nature, by making prescriptive orders about how the river's rights must be protected and implemented and giving itself an ongoing role, via regular reports on implementation from the government. It is remarkable how far the Court has gone in designing institutions to represent the river; inspired by the Te Pou Tupua model, the principle of guardianship, and collaborative governance approach in New Zealand law.

The Te Awa Tupua Act also contains extensive and prescriptive guidance about how the river's rights must be implemented, administered and upheld via a range of

\footnotetext{
${ }^{137}$ Perreault (n 116) 18.
} 
collaborative governance institutions. However, without the river holding any legal right to use its water, and in the context of strong public and private use rights, it is easy to envisage difficulty in prioritising the river's rights. What would happen if a hydroelectric power generator exercised a valid resource consent to use water from the Whanganui River in a manner that impacted negatively on the river's physical or spiritual health? How could Te Pou Tupua agitate for environmental outcomes for the river when the river itself is not a water right-holder and Te Pou Tupua is not a decisionmaker with respect to water? The Te Awa Tupua Act, be it constitutional in nature or otherwise, is an ordinary statute, unable to override rights granted under other legislation. There is yet to be any litigation over the legislation. However, given the potential for conflict over water sharing, the success of the Te Awa Tupua model will depend not only on strong collaborative governance, but on the ability of the courts to resolve disputes. Hopefully, the ongoing proprietary claims Māori maintain to water throughout New Zealand will be resolved in the near future. ${ }^{138}$

Macpherson and O'Donnell have argued that, in order for grants of legal personality to provide opportunities for improved environmental outcomes, they must be accompanied by strong and independent institutions to enforce the river's interests, clearly expressed river values to hold representatives accountable, and legal rights to use the river. ${ }^{139}$ If others have legal or proprietary interests in rivers and the river does not, the scope for enhancing environmental values in river regulation is seriously undermined. However, apart from potential legal avenues for redress proffered by legal standing, the recognition of a river as a 'person' enables a crucial cultural shift in the way we think about rivers. ${ }^{140}$ Such is apparent in the tikanga Māori behind the Tupua te Kawa (river values) adopted for the Whanganui River and the Constitutional Court of Colombia's deference to the relationship of the Atrato communities with the river as a 'space to reproduce life and recreate culture'. ${ }^{141}$ This cultural shift could subversively change our approach to managing rivers, in policy development and before the courts.

\footnotetext{
${ }^{138}$ For a discussion of Māori substantive claims to water rights see Waitangi Tribunal 'The interim report on the national freshwater and geothermal resources claim' (Waitangi Tribunal 2012) http://www.waitangi-tribunal.govt.nz/doclibrary/public/reports/generic/Wai2358/Wai2358W.pdf. ${ }_{139}$ Macpherson and O’Donnell (n 3).

140 ibid.

${ }^{141}$ Tierra Digna 3.
} 


\section{$<A>6$ Conclusion}

In this article the recognition of rivers as legal persons in Aotearoa New Zealand (Whanganui River) and Colombia (Río Atrato) has been interrogated. Although the legal, political, historical and cultural context for recognition is different in each country, an analysis of the cases presents some interesting conceptual correlations, which help us to understand this emerging transnational idea that a river can be a person. It has been found in both cases that recognising that the river is a person is an accommodation of diverse legal and cultural interests in the river, in order to establish a new relationship between the state and river communities in the interests of improved river governance. Whether either model results in improved river outcomes, or increased indigenous or community jurisdiction to govern, turns not on the fiction that the river is a person but on the surrounding institutional framework, which has been carefully designed to engender enforceability. This is a significant finding because it shows that traditional dichotomies that draw lines between human-centred and earthcentred laws or as the object versus the subject of property or rights fail to capture what legal personality entails. Legal person models are certainly context-specific, but further comparative studies of the Colombian and New Zealand models is needed to examine if and how legal personality improves river governance and state-community relationships, not just for future generations but for the entire human species. ${ }^{142}$

142 ibid 137. 